SYMPHONIA 



\section{Saint Hildegard of Bingen}

\section{SYMPHONIA}

A Critical Edition of the Symphonia armonie celestium revelationum

[Symphony of the Harmony of Celestial Revelations]

WITH INTRODUCTION, TRANSLATIONS, AND COMMENTARY BY

BARBARA NEWMAN

SECOND EDITION

Cornell University Press

Ithaca and London 
CORNELL UNIVERSITY PRESS GRATEFULLY ACKNOWLEDGES

A GRANT FROM THE ANDREW $W$. MELLON FOUNDATION

THAT AIDED IN BRINGING THIS BOOK TO PUBLICATION

\section{Copyright $\odot$ 1988, 1998 by Cornell University}

All rights reserved. Except for brief quotations in a review, this book, or parts thereof, must not be reproduced in any form without permission in writing from the publisher. For information, address Cornell University Press, Sage House, 512 East State Street, Ithaca, New York 14850.

First edition published 1988 by Cornell University Press.

Second edition published 1998.

Cornell University Press strives to use environmentally responsible suppliers and materials to the fullest extent possible in the publishing of its books.

Such materials include vegetable-based, low-VOC inks and acid-free papers that are also either recycled, totally chlorine-free, or partly composed of nonwood fibers. For further information, visit our website at www.cornellpress.cornell.edu.

\section{Library of Congress Cataloging-in-Publication Data}

Hildegard, Saint, rog8-r r79.

[Symphonia armonie celestium revelationum. English and Latin.] Symphonia :

a critical edition of the Symphonia armonic celestium revelationum [Symphony of the harmony of celestial revelations] / Saint Hildegard of Bingen; with introduction, translations, and commentary by Barbara Newman. 2nd ed.

$$
\text { p. } \mathbf{c m} \text {. }
$$

Includes bibliographical references and index.

English and Latin.

ISBN-r 3: 978-0-8014-8547-3 (pbk. : alk. paper)

ISBN-ro: o-80r 4-8547-9 (pbk. : alk. paper)

r. Hymns, Latin (Medieval and modern) 2. Chants (Plain, Gregorian, etc.)

$$
\begin{gathered}
\text { I. Newman, Barbara, 1953- } \\
782.25 \text { '0268-dc2 I } \\
98-9609
\end{gathered}
$$

Paperback printing 10 98765432

Cover illustration: Hildegard of Bingen, wood polychrome sculpture (I $4^{\text {th }}$ century), church of St. Peter and Paul, Münster-Sarmsheim (diocese of Trier). Reproduced by permission. 
Omnis caelestis harmonia speculum divinitatis est, et homo speculum omnium miraculorum est Dei.

All celestial harmony is a mirror of divinity, and man is a mirror of all the miracles of God,

Saint Hildegard, Causes and Cures 
